Mark Ludwig, Inga Oelrichs*

\title{
More than a marginal phenomenon: Rel- evance and content-related aspects of mediated sport scandals
}

\author{
Mehr als nur ein randständiges Phänomen: Relevanz und in- \\ haltliche Aspekte medialer Sport-Skandalberichterstattung
}

DOI 10.1515/sug-2020-0011

Summary: The salience of mediated scandals today is deeply linked with the formation of norms and values in our society. This is a particular challenge for the field of sport as the compliance with norms and values is of particular relevance in this social area. The paper shows the extent of scandalization in sport reporting and discusses possible implications for sport. Therefore, it offers a definition and typology for sport scandals. It indicates why sport scandals might have a fundamental share of overall scandal reporting today in comparison to other fields of society. The paper further emphasizes content-related aspects such as celebrity status, sport discipline and type of sport scandal. In the empirical portion, a quantitative content analysis of all reported scandals in three German newspapers over a period of one year is provided. Implications of the findings for athletes, organizations, and society are discussed.

Keywords: sport, scandal, content analysis, media, typology

Zusammenfassung: Im Zuge ihrer gewachsenen medialen Bedeutung tragen Skandale maßgeblich zur Formation und Diskussion des gesellschaftlichen Normen- und Werteverständnisses moderner Gesellschaften bei. Dies stellt besonders für den Sport eine Herausforderung dar, da die Einhaltung von Normen und Werten in diesem gesellschaftlichen Teilbereich eine besondere Bedeutung innehat. Der Beitrag zeigt das Ausmaß medialer Skandalisierung in der Sportberichterstattung auf und diskutiert mögliche Folgen für den Sport. Hierfür werden zunächst eine Definition und eine Typologisierung von Sportskandalen entwickelt

\footnotetext{
*Dr. Mark Ludwig: Deutsche Sporthochschule Köln, Institut für Kommunikations- und Medienforschung, Am Sportpark Müngersdorf 6, 50733 Köln, E-Mail: ludwig@dshs-koeln.de Dr. Inga Oelrichs: Deutsche Sporthochschule Köln, Institut für Kommunikations- und Medienforschung, Am Sportpark Müngersdorf 6, 50733 Köln, E-Mail: i.oelrichs@dshs-koeln.de
} 
und unterschiedliche Gründe einer zunehmenden Sport-Skandalberichterstattung aufgezeigt. Im empirischen Teil werden die Befunde einer quantitativen Inhaltsanalyse zur Berichterstattung über Skandale in drei Tageszeitungen im Zeitraum eines Jahres dargestellt. Abschließend werden Auswirkungen der Berichterstattung für Sportler, Sportorganisationen und den Sport in unserer Gesellschaft diskutiert.

Schlüsselwörter: Sport, Skandal, Inhaltsanalyse, Medien, Typologie

\section{Introduction}

In recent years, there has been a growing interest in sport scandals, both in media practice and research. It is widely acknowledged in both fields that in the age of mass media, sport scandals have become a relevant phenomenon (Storm and Wagner 2015). In a common understanding, a scandal refers to an assumed or proved transgression that becomes known to others and elicits a public response (Adut 2005; Thompson 2000).

According to Burroughs and Vogan (2015: 87), there is a "growing body of scholarship on sport scandals". For example, previous studies of sport scandals have indicated the impact of scandals on sport consumption from a marketing perspective. While Hughes and Shank (2005) focused on aspects of sport scandals that influence the perception of the impact of a scandal case, Prior et al. (2013) developed a model of impacts on sport consumption activities such as ticket sales, viewships or merchandise sales. Further studies examine effects on specific stakeholders, such as fans (Chien et al. 2016; Solberg et al. 2010), sponsors (Connor and Mazanov 2010), investors (Hughes and Shank 2005; Mazanov et al. 2012), and news outlets (Denham 2019). In addition, several studies have analysed specific cases or types of scandal and their reporting in the mass media (e.g., Rowe 2017; Villeneuve and Aquilina 2016; Ward 2014).

In view of the documented impact of sport scandals, recent studies have repeatedly indicated that there is a need for more comprehensive empirical based content analyses in this field (Burroughs and Voghan 2015; Storm and Wagner 2015).

To know more about the extent and types of sport scandal reporting quantitative research is important from at least four perspectives. First, quantitative research in this area helps to assess whether sport can be considered an area where scandal reporting plays a more important role than in other social areas. In addition, insights into different types of scandals and particularly affected disciplines may sharpen the analytical view on and structuration of the field. 
Second, results on the types and frequency of sport scandals will also help to assess and discuss the functions generally fulfilled by the current reporting of sport scandals in society. Previous research has indicated that with the uncovering and negotiation of misconduct, scandals contribute to the consolidation of norms and values in society (Hondrich 2002) or legitimately challenge traditional norms and values - e.g., gendered or racialized attitudes. As the salience of mediated scandals is apparently deeply linked with the general formation of norms and values in our society and sport scandals are able "to resonate beyond the important but still limited world of athletes" (Rowe 2019) sport scandals could be an important part of the scandal driven formation processes of norms and values in our society. Therefore, there is a great interest in knowing more about the types of scandals that are shaping this process.

Third, recent research has also indicated that exaggerated scandal reporting might lead to disruptive effects (Kepplinger 2018). The recipients of such media reporting might become numb and apathetic to scandalization. Moreover, a superfluity of scandal reports could prevent learning effects, as people could feel overburdened and would not be able to draw the appropriate lessons from scandal reports (Hondrich 2002). In the presence of a large number of scandals, recipients might even lose trust in the societal order. Bearing these points in mind, it is important to know more about the extent and frequency of sport scandal reporting.

Fourth, empirical results will establish a basis for sports organizations and athletes to assess the relevance and risk potential of sport scandal reporting.

So far, Osborne, Sherry and Nicholson's study (2016) is the only one that analyses cross sectional reporting on scandals from a sport media perspective. However, their study is limited to professional male athletes' off-field misbehaviour. Accordingly, there is still a need for more comprehensive studies that include different kinds of athletes and transgressions off and on the field. Moreover, there is still a lack of empirical data that allow comparisons between the importance of scandal reporting in sport and other social areas.

Therefore, the aim of this study is to generate insights into the relevance of sport scandals compared to other fields of society and to reveal content-related structures of the reporting on sport scandals. In particular, this study will examine the extent to which sport scandals have been established as a relevant subject in the mass media and which types of scandal are of particular importance in the reporting of sport scandals in Germany. 


\section{Literature review and theoretical background}

\subsection{Sport scandals: Definition and typology}

In everyday life, as well as in daily reporting, diverse incidences might be categorized as scandalous. From a scientific viewpoint, the various definitions of scandal have at least three characteristics that occur in sequence. In line with Thompson's (2000) seminal work, a scandal is a transgression of social norms or values that is denounced publicly and, thereafter, arouses public indignation. Ludwig and Schierl (2016) emphasize that, in this process, the scandalized transgression might have actually occurred or it might only be assumed to have happened.

A further important aspect of contemporary scandals is that mass media play a highly influential role as they can be seen as a key prerequisite to bring scandalous transgressions to a broader audience. This aspect is acknowledged in numerous publications (Burkhardt 2011; Imhof 2002; Kepplinger et al. 2012; Thompson 2000). Therefore, contemporary scandals can be specified as 'mediated scandals' (Thompson 2000). Thompson (2000: 31) indicates that "[m]ediated scandals are not simply scandals which are reported by the media and exist independently of them; they are, in varying ways and to a certain extent, constituted by mediated forms of communication". Moreover, such transgression might also be integrated in a wider social context, and with journalists investigating the incident, the transgression might be enhanced with further facts and speculations. This often leads to ongoing reporting, further condemnation, allegations of additional transgressions, and a broadening of the scandalous case.

These general characteristics of mediated scandals can also be applied to the definition and description of sport scandals. Thematically, sport scandals are related to the field of sport in different ways. On the one hand, they can directly relate to various aspects of sports competitions or the organization of sport and sport events. On the other hand, they can also relate to assumed incidents that are not directly related to the field of sport, but are caused by actors from the world of sport-for example, the manifold sport scandals involving the private affairs of sports celebrities (Rowe 1997) or off-field misbehaviour (Osborne et al. 2016).

Therefore, based on the aspects discussed above, sport scandals can be defined as a particular form of mediated scandals, including 
- at least one (assumed) transgression of norms or values related to the area of sport by either focusing on misbehaviour related to sport competitions, the organization and structures of sports, and/or persons or institutions from the world of sports,

- a publication and condemnation of the (assumed) transgression through mass media, and

- public indignation regarding the transgression that is generally published in media reporting.

For a more detailed differentiation, three types of sport scandals can be further distinguished. The first is referred to as a competition-related sport scandal; it is closely connected to a sporting contest or related sports training situations and its values of fairness and sporting behaviour. In this category, doping scandals are the most prominent (Carstairs 2003; Laine 2006; Solberg et al. 2010). A wellknown case is cyclist Lance Armstrong (Hambrick et al. 2015; Zurloni et al. 2015) who was accused of doping. Other transgressions in this category relate to violent or unfair behaviour: For example, Mike Tyson biting Evander Holyfield's ear at a boxing match for the WBA Heavyweight Championship in 1997 (Hoffer 1998) or Zinedine Zidane's head-butt in the World Cup Final 2006 (Denham and Desormeaux 2008). Like doping, these offences also violate values of sportsmanship.

The second type of sport scandal is the structurally conditioned sport scandal, which also occurs in the sporting environment but is not directly related to the sport competition. This type of scandal is related to transgressions committed at the organizational level of sport. Corruption and manipulation in the context of sport events are prominent examples of this type, such as the 2015 FIFA corruption case (Rowe 2017) or the "Calciopoli" Scandal, an Italian soccer scandal where several clubs were accused of having scheduled "complaisant referees for important matches" (Mazanov et al. 2012: 93).

Cases of abuse by coaches or other organizational members are additional examples of scandals that occur at the organizational level in sport. In certain cases, the handling of accusations by governing bodies expand the range of cases-the Penn State Saga (Sanderson and Hambrick 2012) or the Larry Nassar case (Crepeau 2018) are examples of such scandals. Both involve sexual abuse of young athletes.

A third type of sport scandal concerns transgressions in the private lives of athletes or other people who are in power in sport. These scandals are not directly related to sport but might have consequences for the perception of sport. This type is called the off-competition behaviour sport scandal. As Osborne et al. (2016) showed, transgressions in this category can be manifold. In their study, off-field 
misbehaviour ranged from alleged minor incidences like driving recklessly to heavy crimes like murder. Famous examples of this type of scandal are OJ Simpson's alleged murder of his ex-wife and her friend (Rowe 1997), Ray Rice's case of domestic violence (Ferrucci 2016), or Tiger Wood's extramarital affairs (Davie et al. 2010). Rowe (1997) indicates that scandals like these arouse discussion in a wider societal context. Although Osborne et al. (2016) and Rowe (1997) emphasize the importance of celebrity status for the evolution of these types of scandal, lessknown athletes can be accused for scandalous off-competition behaviour as well. An example of an accusation against a less-known athlete is the accusation against the German female rower Nadja Drygalla for her connection with rightwring extremists (Kulish 2012). Although Drygalla was not publicly known before the accusation, the case dominated German news during the London Olympic Games in 2012.

\subsection{Theoretical reasons for the growing importance of mediated sport scandals}

Even if mediated scandals in sport and other areas of society are not a new phenomenon, it is widely acknowledged that there has been a general rise in mediated scandals in Western societies in the previous decades. In the areas of political and economic communication, several studies have shown that there has been an increase in scandal reporting in the recent past (e.g., Allern and Pollack 2012; Kepplinger 1996; for an overview cf. von Sikorski 2018). From a theoretical viewpoint, the assumed rise of mediated scandals can be explained by profound changes in social, economic, and media conditions in the twentieth and twentyfirst centuries (Ludwig et al. 2016), as well as a symptom of deep transformations in the relationship between the public and private spheres (e.g., Sennett 2017).

In line with Thompson (2000, 2011), it can be said that these shifts are deeply associated with mass media communication. Thompson argues that modern mass media creates a "non-reciprocal intimacy at a distance" (2000: 86) and, therefore, also provide an important precondition for public outrage in scandals. Current trends in sports coverage - such as personalization and the "telling of events in the form of stories" (Maguire 2011: 971), which are supported by a wide range of new technological developments (Pedersen et al. 2017), for example, instant replay (Cummins and Hahn 2013) or subjective camera (Cummins et al. 2012) - support the assumption of similar effects in the area of sports. Ed Goren (as cited in Fountain 2005), former president of Fox Sports, speaks of "a constant attempt to get more intimate, to bring the viewer closer to the action" in sport communication. 
Further, increased scandal coverage may be regarded as an effect of a new structural transformation of the public sphere in the twentieth and twenty-first centuries (Habermas 2008), which has consequently led to a stronger economic orientation of mass media. As Imhof (2016: 184) indicates, it can be stated that "[m]edia, which have become both disembedded from their former social and political ties and increasingly dependent on economic expectations and profit-orientation, make scandal their business - with their focus on persons, on emotions and morale, scandals fit the news values of commercialized media”. In line with Tumber (1993: 359), the assumed rise in scandal reporting may thus be regarded as "a direct consequence of the audience-building strategy of the media", beginning with the accelerated commercialization of the media system in the 1970s and 1980s (Hallin and Mancini 2004) in Western societies. In addition, it must be taken into account that the emergence of a wide range of new media in the age of digitalization has once more increased competition in the mass media market in general, and particularly in the sports media marketplace (Connor and Mazanov 2010).

In this context, Tumber and Waisbord (2004: 1147; 2019) argue that "[t]echnological innovations have contributed to turning scandal politics into common features of contemporary democracies", as news on scandals help to obtain content for and to turn attention to new media outlets, such as internet news services. The economic relevance of scandals for media outlets can also be observed in the field of sport communication. In their case study on the Manti Te'o Hoax, Burroughs and Vogan (2015: 87) indicated that sport scandals function as "instruments through which media outlets fashion their brands, critique competitors, and compete for market share", and as strategic tools in order "to build and assert their status in a shifting, congested, and increasingly digital sport-media industry" (Burroughs and Vogan 2015: 92). Moreover, sport scandals play an important role in the sports entertainment industry. Carstairs (2003: 264) emphasizes that mediated sport scandals serve as an "additional frisson of excitement", which can also attract non-fans that are interested in the "life-shattering events" in which athletes are often involved.

Furthermore, the ongoing process of digitalization has led to new opportunities for public investigations and, therefore, may foster scandal coverage. Connor and Mazanov (2010: 31) indicated that "new communication forms allow for the capture and reporting of events that would previously have remained unknown". This can, for example, be seen in the case of the so called "Panama papers" (Obermayer and Obermaier 2016), a data leak that revealed, amongst other things, dubious business practices of various sport stars and organisations.

These developments are intertwined with developments in the area of sport itself, which may also foster mediated sport scandals. The move from amateurism 
to professionalism and the ongoing commercialization of elite sports, that has been particularly forced by global media marketing, has also opened new channels for threats and disturbances, such as corruption in connection with major sporting events or betting fraud (Mazanov et al. 2012).

In addition, it can be argued that the formation of a star system in sport, which is comparable to star systems in the entertainment industry (Bertling 2009; Rowe 1997), "allows for easy critique of any behaviour that does not live up to an idealised image“ (Connor and Mazanov 2010: 30). Sport stars are also more vulnerable to scandalization because they get more media attention for their transgressions due to their celebrity status. In a study on the role of celebrity status for media reporting of off-field behaviour by male athletes in Australia, Osborne, Sherry and Nicholson (2016) showed that the celebrity status of an athlete contributed significantly to the frequency of articles that were published in off-field scandal. Rowe (1997: 210) also emphasizes the discrepancy between the ideal and constraints of reality in the area of sport: "In spite of the highly advanced commercialization of sport, athletes are still expected to be chiefly motivated by love of sport and of nation."

\section{Research questions}

Responding to the lack of empirical studies on sport scandals, beyond the investigation of influential individual cases and specific types of scandals, the aim of this study is to provide insights into the relevance and content-related aspects of mediated sport scandals. Based on the given theoretical considerations four major research questions are considered to clarify the focus of this study.

As argued above the described changes of social, economic, and media conditions in the twentieth and twenty-first centuries also apply to the field of sport. In particular, trends of personalization in sport reporting (Maguire 2011), the economic relevance of sport scandals for media outlets (Burroughs and Vogan 2015), and the use of new communication forms in sport reporting (Connor and Mazanov 2010) were emphasized. In addition, professionalism and the ongoing commercialization of elite sports also favour the occurrence of mediated sport scandals by opening new channels for transgressions. One of the primary objectives of this study is to provide initial data on the extent to which these trends may have led to the growing importance of mediated sport scandals. 
Therefore, the following is the first key research question:

RQ1: To what extent have sport scandals been established as a subject in contemporary scandal coverage?

The way in which scandals have been established an important subject of contemporary scandal coverage can be empirically described by

1a) the amount of reporting on sport scandals and

1b) the share of sport scandals in the total number of scandals in all fields of society.

As shown above, different types of sport scandals can also be identified. In line with the discussed studies - which indicate a trend of personalization and intimization of sport and scandal reporting (Maguire 2011), a change in the relationship between the public and private spheres (Sennett 2017), and an ongoing commercialization of sports leading to issues like corruption (Mazanov et al. 2012) it can be assumed that, apart from competition-related sport scandals, structurally conditioned sport scandals and off-competition behaviour sport scandals must play an important role as well. Since previous research has not been able to achieve a deeper insight into the internal structure of mediated sport scandals, our research addresses the following question as well:

$R Q$ 2: To what extent different types of sport scandal are addressed in sport scandal coverage?

In addition, the literature review has shown that, in scandal coverage as well as in sport, a focus on celebrities is often emphasized (Connor and Mazanov 2010; Osborne et al. 2016; Rowe 1997). Nonetheless, scandal reports on cases of lesserknown sportspersons were found as well. This point leads to the third question:

$R Q$ 3: How important is the celebrity status of a person involved in a scandal for sport scandal coverage?

Finally, it is of particular interest to explore whether certain sport disciplines are more prone to scandal in news reporting than others. Generally, it can be assumed that disciplines or events that usually get more attention from public media do have a higher share in the reporting of sport scandals as well. Football is the sport that receives by far the most media attention in Germany, followed by winter and motor sports (Ihle 2018). These disciplines are usually the ones that 
are the most commercialized. Therefore, they may be the most susceptible to scandal. This point raises the last research question for our analysis:

RQ4: Are there certain sport disciplines that are more prone to scandal in sport scandal coverage?

\section{Materials and methods}

\subsection{Method of data collection}

A quantitative content analysis (Krippendorff 2019) was conducted to explore the relevance and content-related structures of sport scandals. In the analysis, the number of scandals and articles on these cases, as well as specific characteristics of cases, were counted to provide details about occurrences and distributions. To this end, data on a wide range of scandals reported in German newspapers and relating to different fields of society, collected in a previous study by Oelrichs (2017), were used and re-analysed with a special focus on sport.

\subsection{Material}

Reports on scandals in German daily newspapers were selected as analysis material. The study focused on newspapers, as their daily reports on a vast variety of relevant societal issues usually include all major ongoing scandals. As German newspapers traditionally include comprehensive content on different fields of society, reaching a broad audience, they were particularly suitable as a research object for this study. In addition, the newspaper market is currently particularly affected by the growing competition in the mass media market (Röper 2018). Therefore, newspaper reports may represent the assumed trend of extended scandal reporting as a consequence of the commercialization of the media system (as discussed above) in a particular way.

In Germany three kinds of newspapers can be distinguished. Firstly, nationally distributed so-called quality newspapers that focus on profound reporting of political and economic topics. Secondly, and in comparison to the so-called quality papers, there are tabloid papers with a focus on sensational reporting including reports on scandals. Thirdly, there is a wide range of regional newspapers with a focus on regional as well as national topics. 
For this study typical representatives of each category were chosen to represent the range of newspapers in German and possibly different approaches in scandal reporting. The Süddeutsche Zeitung is the leading national so-called quality newspaper and Bild is the most important German tabloid newspaper with the largest circulation. Kölner Stadt-Anzeiger can be regarded as a typical representative of the wide spectrum of regional newspapers in Germany. These newspapers may differ in scandal reporting as tabloid newspapers are usually known for focussing on scandal and gossip. With this in mind, the results were also checked for differences between the three analysed newspapers.

A two-step procedure was used to identify scandals. As a first step, all title pages as well as each first page of a newspaper section (politics, economics, sport, and society) were scanned for articles that focused on scandalous transgressions. This was done in order to identify all prominently reported transgressions in the selected newspapers.

In a second step, all following articles related to the detected transgressions in each of the three newspapers were selected. If there was condemnation and public denunciation in at least one of the following articles on that transgression, the cases were classified as scandals in line with the three characteristics defined by Thompson (2000). Condemnation and public denunciation could be expressed through a chorus of outrage or the demand for personal consequences or the change of regulations. All articles referring to these scandals were considered in the analysis. In total, the sample included 138 scandalous transgressions from all fields of society, with a total of 3235 articles within one year (2012).

\subsection{Measurements}

The coding unit for this study was the scandal as a case. In order to collect information on the relevance of sport scandals (RQ1), the number of scandals and the number of articles per scandal in different fields of society (politics/administration, economy, arts/culture/showbusiness, research, medicine, military, sport, media, religion, judiciary, nobility, other) were coded for all scandals. For a closer analysis of sport scandals (RQ 2-RQ4) further coding was performed. Three more variables were coded: 1 ) the type of sport scandal (competition-related sport scandal, structurally conditioned sport scandal, off-competition behavior scandal), 2) the sport discipline in which the scandal occurred and 3) the celebrity status of the major transgressor ${ }^{1}$. Two coders analysed the whole material.

1 Celebrity status was defined as the perceived degree of publicity of a sports person ("no celebrity status (ordinary people)", "minor celebrity status (athletes or officials with rare media presence, usually only locally known people)", "moderate celebrity status (athletes or officials with 
Intercoder reliabilities were calculated using Krippendorf's $\alpha$, ranging from 0.9259 (celebrity status) to 1.0 (sport discipline).

\section{Results}

\subsection{Relevance of sport scandals in contemporary scandal coverage}

With regard to RQ1, which questions the extent to which sport scandals have been established as a relevant subject in contemporary scandal coverage, it can be stated that they have an important share of mediated scandalization in the analysed material. As shown in Figure 1, 39 of the 138 scandals could be attributed to a transgression caused by a person from the field of sports (28\%). Therefore, compared to other fields of society, scandals in sport are most frequent. The 35 cases of transgressions of politicians have a similar frequency (25\%). These are followed by cases on transgressors from the field of economics (20 cases, 15\%) and art/culture/show business (16 cases, 12\%).

The number of articles on scandals also indicates the significance of sport scandals: 906 of the 3235 articles (28\%) were on sport scandals; the average number of articles per sport scandal was 23.3.

The average number of articles per scandal in other fields of society was 23.5. Thus, it can be said that the average number of articles per scandal in sport scandal coverage is similar to that of other scandals. Only the number of articles on scandals in politics was higher, with a total of 1334 articles (41\%; average of 38.1 articles per scandal). However, the average number of articles per scandal must be interpreted with caution, because the deviation between the number of articles per scandal is fairly high (SD: 59.3).

infrequent media presence)", "high celebrity status (athletes or officials with regular media presence)", "highest celebrity status (nationally known sport stars, internationally known sport stars e.g. Ronaldo, Bolt, Armstrong, officials in international associations, e.g. Blatter, Ecclestone)". For a wider definition of the concept of "celebrity” cf. Driessens 2013. 


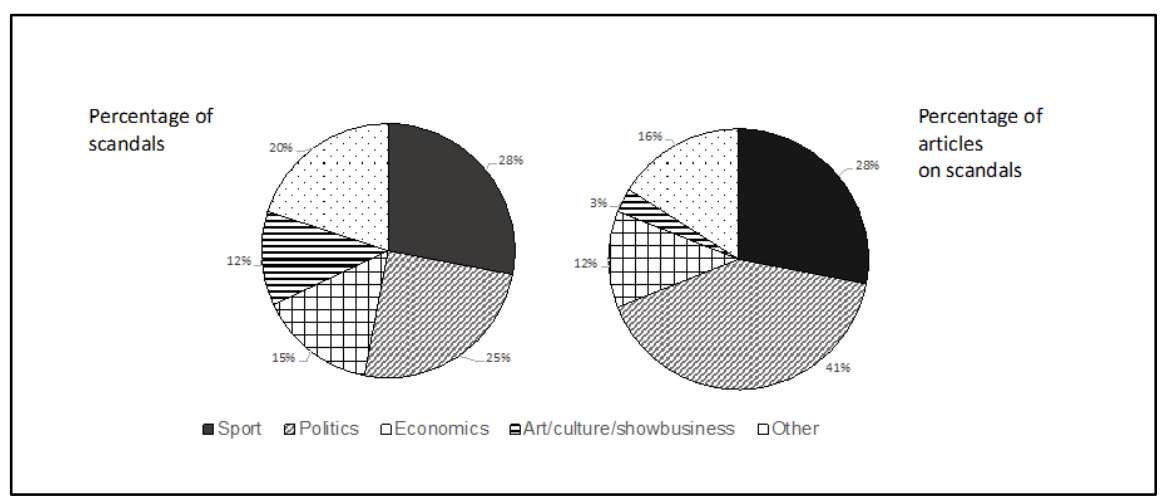

Figure 1: Percentage of scandals and percentage of articles on scandals in different fields of society

There were several cases with a huge number of articles in the newspapers. However, cases that had only a few articles written on them were even greater in number. Figure 2 illustrates the number of articles per scandal for the 39 sport scandals (upper chart) and the number of articles per scandal from other fields of society (lower chart). Three-fourths of the total sport scandals were reported in no more than 23 articles, most of them with an even lower number of mentions (median: 12) in all three newspapers. One case, the doping offence by Lance Armstrong, stood out with 186 articles. Similar to the sport scandals, three-fourths of the cases in other fields of society were reported to have been covered in no more than 23 articles, most of them with a lower number of mentions in the newspapers (median: 9). Outlier cases with a large number of articles could also be observed in other fields of society.

The majority of the 39 sport scandals were reported in all of the three analysed newspapers. The Süddeutsche Zeitung reported on all 39 cases, whereas Bild and Kölner Stadt-Anzeiger reported on 34 cases. The Süddeutsche Zeitung also was the newspaper with the highest amount of articles on sport scandals (444), followed by Kölner Stadt-Anzeiger (247) and Bild (215). 


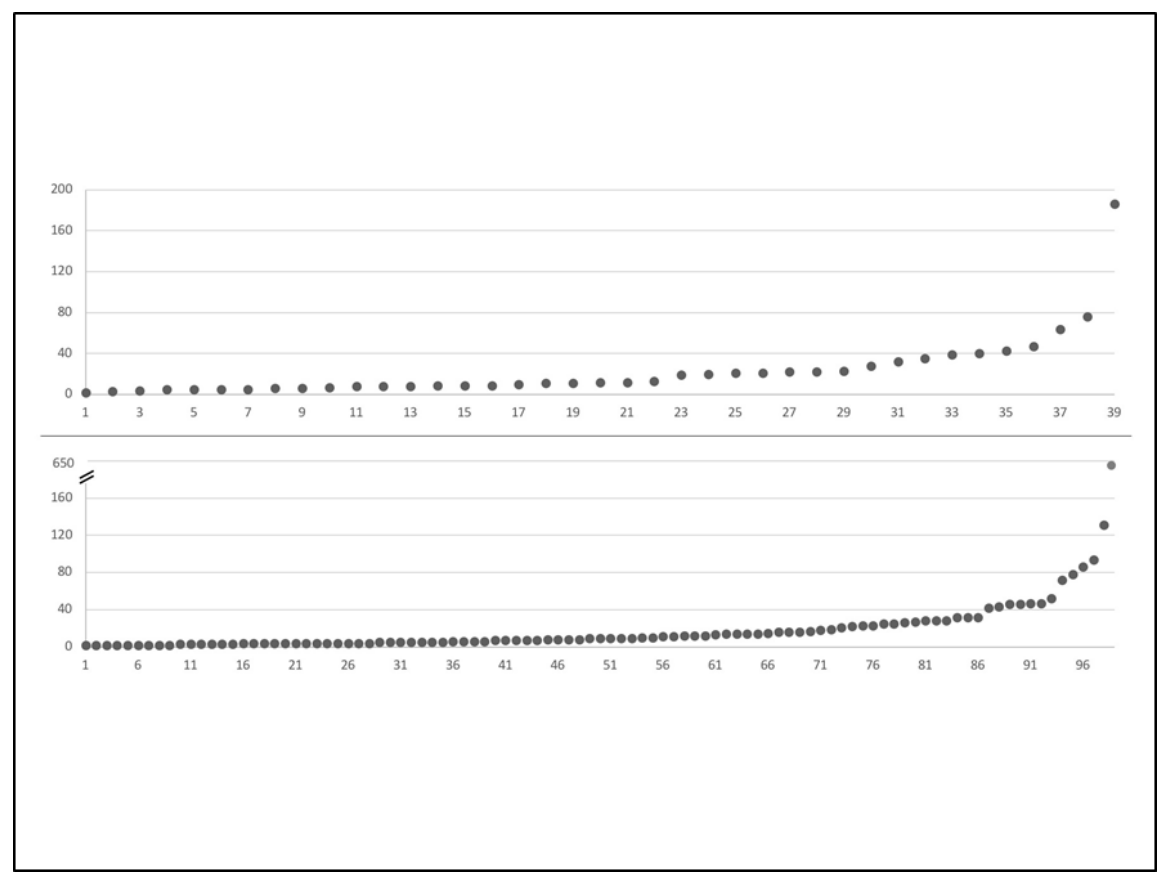

Figure 2: Number of articles on the 39 sport scandal (upper chart) in comparison to number articles on the scandals in other fields of society (lower chart).

\subsection{Types of sport scandal}

With regard to RQ2 (“different types of sport scandals”), it can generally be stated that competition-related sport scandals are most frequent (see Table 1). 22 of the 39 sport scandals, which is over half of the cases, were related to the sporting contest. A closer examination of the cases in this category shows that 8 of the 22 cases deal with doping offences. The case of Lance Armstrong was the most prominent, with 186 articles. Other cases among competition-related sport scandals contained undesirable behaviour, such as brawls among players and referees or vulgar gestures.

Apart from the competition-related sport scandals, there were also structurally conditioned sport scandals and off-competition behaviour scandals in the analysed material-these were almost equal in number. Structurally conditioned sport scandals often focused on corruption (e.g. the case of FIFA boss, Joseph Blatter) and bribery (e.g. the case of Bernie Ecclestone). Allegations of match 
fixing were also mentioned in the media. Examples of off-competition behaviour scandals from the analysed material are Miso Brecko's accident after driving drunk, Marcelinho's attempted rape, or Breno starting a fire in his own house to cheat his insurance company. Apart from these criminal offences, there were also transgressions in moral terms, such as private contact with right-wing extremists or party before a competition.

An examination of the number of articles per scandal reveals that, although competition-related scandals are most frequent, their median number of articles per scandal is small. Numerous competition-related sport scandals were reported only in a few articles. Cases in this category often appear to have been given short-term attention in the newspapers and only rarely lead to further investigation. Off-competition behaviour scandals and structurally conditioned sport scandals appear to be discussed more thoroughly.

Table 1: Type of sport scandal

\begin{tabular}{|c|c|c|c|c|c|c|c|}
\hline \multirow[b]{2}{*}{$\begin{array}{l}\text { Competition- } \\
\text { related sport } \\
\text { scandal }\end{array}$} & \multicolumn{2}{|c|}{$\begin{array}{l}\text { Number and } \\
\text { percentage of } \\
\text { scandals }\end{array}$} & \multicolumn{2}{|c|}{$\begin{array}{l}\text { Number and per- } \\
\text { centage of arti- } \\
\text { cles }\end{array}$} & \multirow{2}{*}{$\begin{array}{c}\text { Median ar- } \\
\text { ticles per } \\
\text { scandal }\end{array}$} & \multirow{2}{*}{$\begin{array}{c}\text { Mean ar- } \\
\text { ticles per } \\
\text { scandal }\end{array}$} & \multirow{2}{*}{$\begin{array}{c}\text { SD } \\
38.6\end{array}$} \\
\hline & 22 & $56.4 \%$ & 460 & $50.8 \%$ & & & \\
\hline $\begin{array}{l}\text { Structurally } \\
\text { conditioned } \\
\text { sport scandal }\end{array}$ & 8 & $20.5 \%$ & 240 & $26.5 \%$ & 22,5 & 30 & 26.5 \\
\hline $\begin{array}{l}\text { Off-competi- } \\
\text { tion behaviour } \\
\text { scandal }\end{array}$ & 9 & $23.1 \%$ & 206 & $22.7 \%$ & 21 & 22.9 & 13.7 \\
\hline Total & 39 & $100 \%$ & 906 & $100 \%$ & 12 & 23.3 & 31.7 \\
\hline
\end{tabular}

\subsection{Celebrity status of the transgressor}

With regard to RQ3 ("importance of celebrity status"), the analysed data show that the reported scandals were on transgressors with minor to highest celebrity status (Table 2, for a closer definition of "celebrity status" cf. footnote 1). However, when focusing on the number of articles per scandal, an accentuation of cases with prominent transgressors becomes evident. Although only about a quarter of the cases were related to people with the highest celebrity status $(25,6 \%)$, almost half the articles were on these cases $(48.5 \%)$. A few scandals 
stood out with a high number of articles per scandal, such as the cases on Lance Armstrong (186 articles), Bernie Ecclestone (76 articles), and Joseph Blatter (64 articles). The median reflects the importance of the highest celebrity status for the number of articles per case. The median for the number of articles in this category is twice as high as in categories of lower celebrity status.

Table 2: Celebrity status of the transgressor

\begin{tabular}{|c|c|c|c|c|c|c|c|}
\hline & \multicolumn{2}{|c|}{$\begin{array}{l}\text { Number and } \\
\text { percentage of } \\
\text { scandals }\end{array}$} & \multicolumn{2}{|c|}{$\begin{array}{l}\text { Number and } \\
\text { percentage of } \\
\text { articles }\end{array}$} & \multirow{2}{*}{$\begin{array}{l}\text { Median artic- } \\
\text { les per scan- } \\
\text { dal }\end{array}$} & \multirow{2}{*}{$\begin{array}{l}\text { Mean artic- } \\
\text { les per scan- } \\
\text { dal }\end{array}$} & \multirow{2}{*}{$\begin{array}{l}\text { SD } \\
- \\
-\end{array}$} \\
\hline $\begin{array}{l}\text { No celebrity } \\
\text { status }\end{array}$ & - & - & - & - & & & \\
\hline $\begin{array}{l}\text { Minor ce- } \\
\text { lebrity sta- } \\
\text { tus }\end{array}$ & 5 & $12.8 \%$ & 75 & $8.3 \%$ & 10 & 15 & 16 \\
\hline $\begin{array}{l}\text { Moderate } \\
\text { celebrity } \\
\text { status }\end{array}$ & 11 & $28.8 \%$ & 170 & $18.8 \%$ & 11 & 15.5 & 14.7 \\
\hline $\begin{array}{l}\text { High celeb- } \\
\text { rity status }\end{array}$ & 13 & $33.3 \%$ & 222 & $24.5 \%$ & 11 & 17.1 & 12.3 \\
\hline $\begin{array}{l}\text { Highest ce- } \\
\text { lebrity sta- } \\
\text { tus }\end{array}$ & 10 & $25.6 \%$ & 439 & $48.5 \%$ & 22 & 43.9 & 55.25 \\
\hline Total & 39 & $100 \%$ & 906 & $100 \%$ & 12 & 23.3 & 31.7 \\
\hline
\end{tabular}

\subsection{The sport of the transgressor}

Finally, the analysis of the affected sport disciplines reveals that mostly popular media sports are in focus when it comes to reporting scandals (Table 3). With regard to RQ4, it was observed that almost two-thirds (64.1\%) of the scandals broached on athletes or officials in football, which is by far the most popular media sport in Germany (Ihle 2018). However, scandals also arose in less popular media sports, such as handball or speed skating.

Although almost two-thirds of scandal cases are related to football, less than half of the articles on scandals $(46,8 \%)$ were related to this sport. This finding implies that the number of articles on scandal in football was, on average, comparatively small. Many of the cases in football were picked up by the media only for a few days. In contrast, it also becomes evident that there are a fairly large number of cases on scandal in sport disciplines that usually do not get much 
media attention. For example, a scandal about a female rower was reported in over 40 articles.

When comparing the types of sport scandals and the sport disciplines in which these scandals occur, a correlation was found (Cramer's V $=0.46$ ). While transgressions in football could be found in all three types of scandals, all the cases in cycling were on doping and were, therefore, categorised as competitionrelated sport scandals.

Table 3: Sport of the transgressor

\begin{tabular}{|c|c|c|c|c|c|c|c|}
\hline \multirow[b]{2}{*}{ Football } & \multicolumn{2}{|c|}{$\begin{array}{l}\text { Number and } \\
\text { percentage of } \\
\text { scandals }\end{array}$} & \multicolumn{2}{|c|}{$\begin{array}{l}\text { Number and } \\
\text { percentage of } \\
\text { articles }\end{array}$} & \multirow{2}{*}{$\begin{array}{c}\text { Median ar- } \\
\text { ticles per } \\
\text { scandal }\end{array}$} & \multirow{2}{*}{$\begin{array}{l}\begin{array}{c}\text { Mean arti- } \\
\text { cles per } \\
\text { scandal }\end{array} \\
16.9\end{array}$} & \multirow{2}{*}{$\begin{array}{r}\text { SD } \\
14.3\end{array}$} \\
\hline & 25 & $64.1 \%$ & 424 & $46.8 \%$ & & & \\
\hline Cycling & 6 & $15.4 \%$ & 249 & $27.5 \%$ & 8.5 & 41.5 & 72.1 \\
\hline Handball & 1 & $2.6 \%$ & 8 & $0.9 \%$ & 8 & - & - \\
\hline Athletics & 2 & $5.1 \%$ & 32 & $3.5 \%$ & 16 & 16 & 5.7 \\
\hline Formula 1 & 2 & $5.1 \%$ & 84 & $9.3 \%$ & 42 & 42 & 48.1 \\
\hline Rowing & 1 & $2.6 \%$ & 43 & $4.7 \%$ & 43 & - & - \\
\hline Boxing & 1 & $2.6 \%$ & 47 & $5.2 \%$ & 27 & - & - \\
\hline Speed skating & 1 & $2.6 \%$ & 19 & $2.1 \%$ & 19 & - & - \\
\hline Total & 39 & $100 \%$ & 906 & $100 \%$ & 12 & 23.3 & 31.7 \\
\hline
\end{tabular}

\section{Discussion}

As mentioned in the literature review, prior research on sport scandals has generally indicated that sport scandals can be regarded as an important phenomenon of our time. However, it was found that there is a lack of empirical studies in this field that enable a systematic analysis and documentation of this phenomenon from quantitative and mass media perspectives. Therefore, based on a content analysis, the present study was designed to assess the relevance of sport in scandal communication and to present specific content-related aspects of the reporting of sport scandals in detail.

As a first major result with regard to RQ1, it was clarified that sport scandals play an important role in contemporary scandal reporting. These findings correspond to theoretical assumptions that propose an expansion of scandal reporting in fields apart from politics, such as sports, arts, and economics (Eisenegger 2016; Imhof 2016). This development can be explained from different perspectives. Among other things, the development results from a new structural transformation of the public sphere (Habermas 2008), a commercialization of the media 
system (Hallin and Mancini 2004; Tumber 1993), and a general increased competition in the media sector (Connor and Mazanov 2010), which has been enforced by digitalization and technological innovations (Tumber and Waisbord 2004).

In this regard, it seems interesting that the amount of reported cases did not differ to a greater extent and that the Süddeutsche Zeitung, a quality newspaper, was the one with the highest amount of scandal reports and the highest number of articles. This additional finding supports the assumption of "shifting boundaries of elite and tabloid media" (Välliveronen and Juntunen 2019: 174) that have recently been detected in other fields of scandal reporting and countries, too.

The findings also support the outlined theoretical considerations regarding the increased role of sport in scandal reporting, as mentioned in research in the recent past (Burroughs and Vogan 2015). Nevertheless, the majority of sport scandals in the sample could be explained by specific aspects of sport. Due to specific values, such as fairness or sportsmanship, the field of sports may be particularly vulnerable to violations of norms.

Another important finding is that different types of sport scandals co-exist in sports scandal reporting. With regard to RQ 2, the three types suggested in the theory section emerged as a reasonable and distinct categorization for coding sport scandals.

Further, the data examined show that the most frequent type of sport scandals are competition-related sport scandals. This is not surprising if one bears in mind that sport competition is generally central in sports reporting and that there is a regularity in reporting on recurring sport events. In this regard, reports of sport scandals could be considered "additional frisson or excitement", as indicated by Carstairs (2003: 264).

However, it must be noted that structurally conditioned sport scandals and off-competition behaviour scandals are also reported to a great extent. The remarkable share of off-competition behaviour scandals strengthens the assumption that the reporting of sport scandals can partially be understood as a symptom of a general change in the relationship between public and private spheres and an "intimization" of scandal reporting, as suggested by several authors (Sennett 2017; Thompson 2011), and of a specific trend towards personalization in sports reporting, which is widely assumed in sport communication literature (Maguire 2011).

The reports on structurally conditioned sport scandals support Mazanov et al. (2012) that the professionalization of the sports sector itself has created new issues in the field of reporting of sport scandals (e.g. corruption). In addition, these reports may also indicate a professionalization in sport journalism in terms of a trend towards a more critical coverage of background information. In a digital globally connected world, sport journalists increasingly implement large- 
scale cross-border projects, investigating the dirty underbelly of the sport sector. The current investigations by the "Football Leaks" project are a good example of such a project (Buschmann and Wulzinger 2018).

Moreover, the findings show that a higher celebrity status is not a necessary condition to become a subject of mediated scandal reporting. However, the data do suggest that a particularly high celebrity status leads to a higher probability of intense reporting of sport scandals. These findings corroborate the ideas of Rowe (1997) and Osborne et al. (2016), who suggested that being a celebrity plays a crucial role in this context. An explanation of the importance of celebrity status might be that the amount of discussion about the transgressor in society and the consequent public resonance, which is important for scandalization, might be higher.

A similar picture emerges with regard to RQ4, which questioned the role of certain sport disciplines. The status of a sport being a marginalized one does not seem to protect it from scandals that are reported in mass media. However, the distribution resembles typical patterns of general sport coverage, as football plays an outstanding role as the most popular German sport. Future research that may focus on the predictive factors of scandalization in sport should consider the status of the sport discipline.

As an additional finding, it was observed that the cases examined in the sample differ immensely in terms of frequency and the average number of articles per scandal. This does not seem to be a particular aspect of sport communication, as the analyses of scandal reports in other fields of society roughly have the same patterns. Therefore, a differentiated examination of minor and major scandals could be a promising direction for future research as well.

Finally, limitations of the current study must be acknowledged. First, it must be considered that the present study only included the scandal cases in a period of one year. Individual cases and issues that were of particular interest in that year could have influenced the findings. Therefore, the generalizability of the results is limited. However, it would be almost impossible to generalise any sample on scandal reports because there is generally a strong dependence on special incidents in scandal coverage. The given sample includes the Olympic Games and European Football Championships. In this regard, the examined period can be regarded as a typical sporting year with two major sport events. Nevertheless, future research must account for varying aspects, and also include longitudinal analyses to detect developments in sport scandal coverage over decades.

Second, the research is limited to the reporting of sport scandals in the selected sample. Although the sample seems well suited to represent the range of newspaper scandal reporting in Germany there might be different ways of scandal reporting in other major news outlets in Germany and internationally. In this 
respect, additional research is needed to determine different media and multinational perspectives.

\section{Conclusion}

The present study focused on the relevance and content-related aspects of the contemporary reporting of sport scandals. Therefore, a definition and typology of sport scandals was provided in this study. Based on theoretical considerations, and in line with the current state of research, it was shown that an increased significance of sport scandals can be generally assumed for several reasons. As major aspects of an increased significance of sport scandals a changing relationship between the public and private spheres, technological developments and commercialization of the media were indicated.

Empirically, a quantitative content analysis was conducted to generate first insights into the reporting of sport scandals and offer preliminary data, which go beyond the investigation of individual cases or specific types of sport scandals. The results provide empirical evidence that scandalization has definitely affected the field of sport and the field of media. A key finding is that reporting of sport scandals can obviously not be regarded as a marginal phenomenon anymore.

In a wider context, these findings imply risks for athletes, sport organizations, and trust in the sport system in general. As shown by the results of the present study, there is a tendency towards an ongoing, everyday reporting on a large variety of minor and major sport scandals. Similar to the argumentation by Kepplinger (2012), who indicated that frequent scandalization in the field of politics might lead to decreased trust in political elites, one could argue that frequent reports on sport scandals might also influence the recipients' attitude towards sport in negative manner. Recipients might question the validity of norms and values in sport and might lose their general trust in the system of sport. Moreover, the observed frequent coverage of sport scandals increases the likelihood of the risk that socially desired learning effects might not occur if people are confronted with a superfluity of scandals (Hondrich 2002).

However, the consequence cannot be that journalists stop reporting on scandals completely. As shown in the study, scandals can be beneficial for society, as they can contribute to the consolidation or critical questioning of norms and values in society, disclose misconduct, and prevent socially undesirable behaviour. Therefore, the media must carefully consider the manner and frequency of scandal reporting in order not to waste the social potential and desired positive effects of scandal reporting. In addition, it appears important to avoid false reports in 
order to prevent media from accusations of "fake news" or credibility problems that are currently widely discussed.

In this context, one could also discuss the result of this study that reports of sport scandals do not only focus on sports competitions or the organizational structures of sports but also often report on misconduct in athletes' private lives. Although off-competition behaviour scandals might be helpful for journalists to obtain the attention of their audiences, it is at least questionable if these incidences are always important issues that must be discussed in a wider public sphere. Therefore, future studies should investigate the reasons and effects of the different types of reporting of sport scandals. In addition, further studies should work out in additional qualitative approaches how media report on scandals.

Further, the developments outlined in the paper are also creating huge challenges for all actors involved in sport. In particular, athletes might face a dilemma: on the one hand, it appears important for them to communicate various aspects of their private lives to serve the needs of a commercialized sport and media system. On the other hand, the strongly extended intimization of mass media communication involves risks in terms of scandalization.

There are also consequences of the high relevance of scandals in sport reporting for sport organizations. A possible trend towards a more critical coverage of background information by reporting structurally conditioned sport scandals demands more transparency and good governance practices on the part of sport organizations. With an open, informative attitude, sport organizations could reduce speculative reports about potential misconduct. Further research is needed to develop strategies for sport organizations to meet the demands of a globally linked and fast-developing media society and to develop the right strategies for the treatment of allegations.

Besides these practical implications, this study can be seen as a starting point to a wider research of the contents and effects of mediated sport scandals. Bearing in mind that the salience of mediated scandals is apparently deeply linked with the general formation of norms and values in our society and paying attention to the result of this study that sport scandals play an obviously outstanding role in in contemporary scandal reporting, it appears necessary to further investigate the phenomenon of the sport scandal. The differentiation of competition related sport scandals, structurally conditioned sport scandals and off-competition behaviour scandals could be a helpful structuration to further investigate sport scandal coverage in different media, different cultural contexts, and developments over time. In a next step it should also be considered if and how these sport scandal types differ in ways of reporting.

In conclusion, the present study provides an important basis for further research on sport scandals. It is evident that mediated sport scandals are an issue 
of great importance that must be pursued further from both scientific as well as practical viewpoints.

\section{References}

Adut, Ari (2005): A Theory of Scandal: Victorians, Homosexuality, and the Fall of Oscar Wilde. In: American Journal of Sociology. Vol. 111, Issue 1, pp. 213-248.

Allern, Sigurd/Pollack, Ester (2012): Scandalous! The mediated construction of political scandals in four Nordic countries. Göteborg: Nordicom.

Bertling, Christoph (2009): Sportainment: Konzeption, Produktion und Verwertung von Sport als Unterhaltungsangebot in den Medien. Köln: Herbert von Halem.

Burkhardt, Steffen (2011): Skandal, medialisierter Skandal, Medienskandal: Eine Typologie öffentlicher Empörung. In: Kristin Bulkow/Christer Petersen (Hg.): Skandale. Strukturen und Strategien öffentlicher Aufmerksamkeitserzeugung. Wiesbaden: VS Verlag, S. 131-155.

Burroughs, Benjamin/Vogan, Travis (2015): Media Industries and Sport Scandals: Deadspin, Sports Illustrated, ESPN, and the Manti Te'o Hoax. In: International Journal of Sport Communication. Vol. 8, Issue 1, pp. 87-102.

Buschmann, Rafael/Wulzinger, Michael (2018): Football Leaks. Uncovering the dirty deals behind the beautiful game. London: Guardian Faber.

Carstairs, Catherine (2003): The Wide World of Doping: Drug Scandals, Natural Bodies, and the Business of Sports Entertainment. In: Addiction Research \& Theory. Vol. 11, Issue 4, pp. 263-281.

Chien, P. Monica/Kelly, Sarah Jane/Weeks, Clinton (2016): Sport Scandal and Sponsorship Decisions: Team Identification Matters. In: Journal of Sport Management. Vol. 30, Issue 5, pp. 490-505.

Connor, James Michael/Mazanov, Jason (2010): The inevitability of scandal: Lessons for sponsors and administrators. In: International Journal of Sports Marketing and Sponsorship. Vol. 11, Issue 3, pp. 29-37.

Crepeau, Richard C. (2018): The Nasser Case. [online]. http://stars.library.ucf.edu/cgi/ viewcontent.cgi?article=1821\& context=onsportand society [13.12.2019].

Cummins, Robert Glenn/Hahn, Dustin (2013): Re-presenting Sport: How Instant Replay and Perceived Violence Impact Enjoyment of Mediated Sports. In: Mass Communication and Society. Vol. 16, Issue 6, pp. 787-807.

Cummins, Robert Glenn/Keene, Justin Robert/Nutting, Brandon H. (2012): The Impact of Subjective Camera in Sports on Arousal and Enjoyment. In: Mass Communication and Society. Vol. 15, Issue 1, pp. 74-97.

Davie, William R./King, C. Richard/Leonard, David J. (2010): A Media Look at Tiger Woods - Two Views. In: Journal of Sports Media. Vol. 5, Issue 2, pp. 107-116.

Denham, Bryan (2019): Coverage of the Russian Doping Scandal in the New York Times: Intramedia and Intermedia Attribute Agenda-Setting Effect. In: Communication \& Sport. Vol. 7, Issue 3, pp. 337-360.

Denham, Bryan/Desormeaux, Melissa (2008): Headlining the head-butt: Zinedine Zidane/Marco Materazzi portrayals in prominent English, Irish and Scottish newspapers. In: Media, Culture \& Society. Vol. 30, Issue 3, pp. 375-392. 
Driessens, Olivier (2013): Celebrity capital: redefining celebrity using the field of theory. In: Theory \& Society. Vol. 42, Issue 5, pp. 543-560.

Eisenegger, Mark (2016): Negierte Reputation - Zur Logik medienöffentlicher Skandalisierungen. In: Mark Ludwig/Thomas Schierl/Christian von Sikorski (Hg.): Mediated Scandals. Köln: Herbert von Halem, S. 33-57.

Ferrucci, Patrick (2016): To Tweet and Retweet: NFL Journalists as Gatekeepers in the Ray Rice Scandal on Twitter. In: Journal of Sports Media. Vol. 11, Issue 2, pp. 1-22.

Fountain, Henry (2005): A Chance to Peek Over the Quarterback's Shoulder. [online]. https://www.nytimes.com/2005/01/06/technology/circuits/a-chance-to-peek-over-thequarterbacks-shoulder.html [13.12.2019].

Habermas, Jürgen (2008): The structural transformation of the public sphere: An inquiry into a category of bourgeois society. Cambridge: Polity Press.

Hallin, Daniel/Mancini, Paolo (2004): Comparing media systems: Three models of media and politics. Cambridge: Cambridge University Press.

Hambrick, Marion/Frederick, Evan/Sanderson, Jimmy (2015): From Yellow to Blue: Exploring Lance Armstrong's Image Repair Strategies Across Traditional and Social Media. In: Communication \& Sport. Vol. 3, Issue 2, pp. 196-218.

Hoffer, Richard (1998): A savage business: The comeback and comedown of Mike Tyson. New York: Simon \& Schuster.

Hondrich, Karl Otto (2002): Enthüllung und Entrüstung: Eine Phänomenologie des politischen Skandals. Frankfurt am Main: Suhrkamp.

Hughes, Stephanie/Shank, Matt (2005): Defining Scandal in Sports: Media and Corporate Sponsor Perspectives. In: Sport Marketing Quarterly. Vol. 14, Issue 4, pp. 207-216.

Ihle, Holger (2018): Sport in den Fernsehnachrichten. In: Media Perspektiven. Jg. 10, S. $486-$ 495.

Imhof, Kurt (2002): Medienskandale als Indikatoren sozialen Wandels. Skandalisierung in den Printmedien im 20. Jahrhundert. In: Kornelia Hahn (Hg.): Öffentlichkeit und Offenbarung. Eine interdisziplinäre Mediendiskussion. Konstanz: UVK, S. 73-98.

Imhof, Kurt (2016): Political, social, and economic crisis in public communication. In: Andreas Schwarz/Matthew Seeger/Claudia Auer (ed.): The handbook of international crisis communication research. Chichester: Wiley Blackwell, pp. 175-187.

Kepplinger, Hans Mathias (1996): Skandale und Politikverdrossenheit - Ein Langzeitvergleich. In: Otfried Jarren/Heribert Schatz/Hartmut Weßler (Hg.): Medien und politischer Prozeß. Opladen: Westdeutscher Verlag, S. 41-58.

Kepplinger, Hans Mathias (2018): Die Mechanismen der Skandalisierung. Reinbek: Lau.

Kepplinger, Hans Mathias/Geiss, Stefan/Siebert, Sandra (2012): Framing Scandals: Cognitive and Emotional Media Effects. In: Journal of Communication. Vol. 62, Issue 4, pp. 659-681.

Krippendorff, Klaus (2019): Content analysis: An introduction to its methodology. Los Angeles: Sage.

Kulish, Nicholas (2012): In Germany, Talk of the Olympics Centers on a Rower's Choice of Boyfriend. [online]. https://www.nytimes.com/2012/08/07/sports/olympics/germanysolympics-talk-centers-on-nadja-drygallas-boyfriend.html [15.12.2019].

Laine, Tarja (2006): Shame on us: Shame, national identity and the Finnish doping scandal. In: International Journal of the History of Sport. Vol. 23, Issue 1, pp. 67-81. 
Ludwig, Mark/Schierl, Thomas (2016): Mediated Scandals und ihre Folgeeffekte. Eine einführende Betrachtung der Risiken und Relevanz medialer Skandalberichterstattung. In: Mark Ludwig/Thomas Schierl/Christian von Sikorski (Hg.): Mediated Scandals. Köln: Herbert von Halem, S. 16-32.

Ludwig, Mark/Schierl, Thomas/von Sikorski, Christian (Hg.) (2016): Mediated Scandals. Köln: Herbert von Halem.

Maguire, Joseph A. (2011): The global media sports complex: Key issues and concerns. In: Sport in Society. Vol. 14, Issue 7-8, pp. 965-977.

Mazanov, Jason/Lo Tenero, Gabriele/Connor, James/Sharpe, Keiran (2012): Scandal+football=a better share price. In: Sport, Business and Management: An International Journal. Vol. 2, Issue 2, pp. 92-114.

Obermayer, Bastian/Obermaier, Frederik (2016): The Panama papers: Breaking the Story of How the Rich \& Powerful Hide their Money. London: Oneworld Publications.

Oelrichs, Inga (2017): Skandalfaktoren. Köln: Herbert von Halem.

Osborne, Angela/Sherry, Emma/Nicholson, Matthew (2016): Celebrity, scandal and the male athlete: A sport media analysis. In: European Sport Management Quarterly. Vol. 16, Issue 3, pp. 255-273.

Pedersen, Paul M./Laucella, Pamela C./Kian, Edward (2017): Strategic sport communication (Second edition). Champaign, IL: Human Kinetics.

Prior, Daniel D./O'Reilly, Norm/Mazanov, Jason/Huybers, Twan (2013): The impact of scandal on sport consumption: A conceptual framework for future research. In: International Journal of Sport Management and Marketing. Vol. 14, Issue 1/2/3/4, pp. 188-211.

Röper, Horst (2018): Zeitungsmarkt 2018: Pressekonzentration steigt rasant. In: Media Perspektiven, H. 5, S. 216-234.

Rowe, David (1997): Apollo Undone: The Sports Scandal. In: James Lull/Stephen Hinerman (ed.), Media scandals: Morality and desire in the popular culture marketplace. Cambridge: Polity, pp. 203-221.

Rowe, David (2017): Sports Journalism and the FIFA Scandal: Personalization, Co-optation, and Investigation. In: Communication \& Sport. Vol. 5, Issue 5, pp. 515-533.

Rowe, David (2019): Scandals and Sport. In: Howard Tumber/Silvio R. Waisbord (ed.): The Routledge Companion to Media and Scandal. London and New York: Routledge, pp. 324332.

Sanderson, Jimmy/Hambrick, Marion E. (2012): Covering the Scandal in 140 Characters: A Case Study of Twitter's Role in Coverage of the Penn State Saga. In: International Journal of Sport Communication. Vol. 5, Issue 3, pp. 384-402.

Sennett, Richard (2017): The fall of public man. New York: W. W. Norton \& Company.

Solberg, Harry Arne/Hanstad, Dag Vidar/Thøring, Thor Atle (2010): Doping in elite sport - do the fans care? Public opinion on the consequences of doping scandals. In: International Journal of Sports Marketing and Sponsorship. Vol. 11, Issue 3, pp. 2-16.

Storm, Rasmus K./Wagner, Ulrik (2015): The Anatomy of the Sports Scandal: An Outline for a Theoretical Contextualization. In: International Journal of Sport Communication. Vol. 8, Issue 3, pp. 293-312.

Thompson, John B. (2000): Political scandal: Power and visibility in the media age. Cambridge: Polity Press.

Thompson, John B. (2011): Shifting Boundaries of Public and Private Life. In: Theory, Culture \& Society. Vol. 28, Issue 4, pp. 49-70. 
Tumber, Howard (1993): 'Selling scandal': Business and the media. In: Media, Culture \& Society. Vol. 15, Issue 3, pp. 345-361.

Tumber, Howard/Waisbord, Silvio R. (2004): Introduction: Political Scandals and Media Across Democracies, Volume II. In: American Behavioral Scientist. Vol. 47, Issue 9, pp. 1143-1152.

Tumber, Howard/Waisbord, Silvio R. (2019). Routledge Companion to Media and Scandal. London and New York: Routledge.

Villeneuve, Jean-Patrick/Aquilina, Dawn (2016): Who's fault is it? An analysis of the press coverage of football betting scandals in France and the United Kingdom. In: Sport in Society. Vol. 19, Issue 2, pp. 187-200.

von Sikorski, Christian/Ludwig, Mark (2018): The effects of visual isolation on the perception of scandalized politicians. In: Communications. Vol. 43, Issue 2, pp. 235-257.

von Sikorski, Christian (2018): The Contents and Effects of Political Scandals: A Synopsis. In: André Haller/Hendrik Michael/Martin Kraus (ed.): Scandalogy. An interdisciplinary field. Köln: Halem, pp. 135-154.

Väliverronen, Esa/Juntunen, Laura (2019): The shifting boundaries of elite and tabloid media in political sex scandals. In: Howard Tumber/Silvio R. Waisbord (ed.): The Routledge Companion to Media and Scandal. London and New York: Routledge, pp. 174-192.

Ward, Geoff (2014): The Passion of Tiger Woods: An anthropologist reports on golf, race and celebrity scandal. In: Sport in Society. Vol. 17, Issue 6, pp. 855-858.

Zurloni, Valentino/Diana, Barbara/Cavalera, Cesare/Argenton, Luca/Elia, Massimiliano/Mantovani, Fabrizia (2015): Deceptive behavior in doping related interviews: The case of Lance Armstrong. In: Psychology of Sport and Exercise. Vol. 16, Issue 2, pp. 191-200. 